\title{
EVALUATION OF ANTIOXIDANT AND ANTI- INFLAMMTORY ACTIVITY OF METHANOLIC EXTRACT OF SOLANUM NIGRUM FRUITS
}

\author{
Sinha $\mathbf{R}^{* 1}$, Kaur $\mathbf{D}^{1}$, Kumar $\mathbf{B}^{1}$, \\ ${ }^{1}$ Ram-Eesh Institute of Vocational and Technical Education, Greater Noida, Uttar Pradesh, India \\ ABSTRACT \\ Introduction: Solanum nigrum (Linn) is known as Makoy and Black night shade. It is found in India and in cultivated ground. This plant has \\ been reported for hepatoprotective, antibacterial, antimicrobial, antiseptic, narcotic, antispasmodic, anti-inflammatory, CNS depressant, \\ molluscidal, antiulcer, cardiac depressant, immunomodulatory and antioxidant activities. It is widely used as expectorant, anodyne, vulnerary, \\ digestive, laxative, diuretic, cardiotonic, depurative, diaphoretic, febrifuge, swelling, wounds, ulcer, dyspepsia, ophthalmic disorder, vomiting, \\ cardiac disorder, leprosy, skin disease, fever, splenomegaly, hemorrhoids, hoarseness, nephropathy, dropsy, gonorrhea.Leaves are use as poultice \\ for rheumatic an gouty joints, decoction of berries and flower useful in cough, erysipelas, rat bite, bronchitis, pulmonary tuberculosis, fever, \\ diarrhea, ophthalmopathy and hydrophobia. Root bark is useful in diseases of ear, eye, nose and hepatitis. Material and methods: For anti- \\ inflammatory activity adult wister rats of both sexes weighing between 200-250g was used for experiment. Group-1 received $0.5 \%$ CMC \\ suspension (control) group 2, 3 and 4 received methanolic extracts $(125,250$ and $375 \mathrm{mg} / \mathrm{kg}$ ) of $S$. nigrum respectively. Group 5 received \\ diclofenac (reference standard $1 \mathrm{mg} / \mathrm{kg}$ ). The antioxidant activity of the fruit of $S$. nigrum was determined by using a method based on the \\ reduction of methanolic solution of colored free radical 1, 1 di phenyl-1-2 picryl hydrazyl (DPPH). Result and discussion: Methanolic extract of \\ Solanum nigrum Linn. fruit has shown antioxidant activity in vitro DPPH Method. The methanolic extract of S. nigrum $(375 \mathrm{mg} / \mathrm{kg}) \mathrm{prevented}$ \\ the formation of edema induced by carrageenan and thus showed significant anti-inflammatory activity $(\mathrm{p}<0.05)$. Conclusion: The data \\ collectively indicates that methanolic extract of Solanum nigrum fruits have potential anti-inflammatory and antioxidant activity.
}

Keywords: Anti-inflammatory, Carrageenan, Paw edema, Anti-inflammatory, Antioxidant.

\section{Article info:}

Received: October 07, 2018

Revised: January 16, 2018

Published Online: April 15, 2019

DOI: https://doi.org/10.31069/xxxxxxxx

\section{Correspondence}

Reema Sinha

Ram-Eesh Institute of Vocational \& Technical Education.

3, Institutional Area, Knowledge Park I, Greater Noida

Phone: +91-7838439189

Email: sinhareema2@gmail.com

\section{INTRODUCTION}

India has about 45000 plant species, with over 4000000 registered Ayurvedic practitioners; the Government of India has formal structures to regulate quality, safety, efficacy of herbal medicine named as National policy on Indian systems of Medicine and Homeopathy. ${ }^{[1]}$ The antiseptic qualities of aromatic and medicinal plant extracts were recognized in the laboratory data back to the early. ${ }^{[2]}$ Ayurvedic, remaining one of the most ancient and yet living tradition practices widely in developing as well as developed countries and has a sound philosophical and experimental basis. ${ }^{[3]}$ Approximately $20 \%$ of the plants found in the world have submitted to pharmacological activity. ${ }^{[4]}$

The plant possesses chemotherapeutic, bacteriostatic, antimicrobial agent. ${ }^{[5]}$ The source of plants is models for the synthesis of new drugs with better therapeutic, chemical properties than the original compound. Solanum nigrum Linn, a medicinal plant has been mentioned for the treatment of liver disorders in Ayurveda, an ancient system of medicine. There are many evidences indicates that free radical are responsible for birth of many disorders like inflammation, atherosclerosis, aging and hepatic toxicity. Solanum nigrum is an important medicinal plant of family-Solanaceae and found throughout the country in dry parts. ${ }^{[6]}$ Solanum nigrum has been extensively used in traditional medicine in India and other part of the world to cure liver disorders, chronic skin ailment in inflammatory condition, painful periods fever, diarrhea, eye diseases and hydrophobia. ${ }^{[7]}$

Antioxidants are the compounds which retard or prevent the oxidation in general and prolong the life of oxidizable matter. The antioxidant activities of the individual compounds may depend on structural factors such as number of phenolic, hydroxyl or methoxy groups and other structural features. ${ }^{[8]}$ Among the antioxidant compounds vitamin A, C, E, selenium, carotenoids, ascorbic acid shows very strong intensity of antioxidant activities. ${ }^{[9]} \mathrm{A}$ free radical is a compound with one or more unpaired electrons in its outer orbital. Such unpaired electrons make these species very unstable and therefore quite reactive with other molecules due to the presence of unpaired electrons and try to pair their electrons and generate a more stable compound. ${ }^{[10]} \mathrm{A}$ molecule of 1, 1diphenyl-2-picyl-hydrazyl (DPPH) is characterized as a stable free 
radical by virtue of the delocalization of the spare electron over the molecule as a whole, so that molecules do not dimerize, as would be the case with most other free radicals. The delocalization also gives rise to the deep violet color, characterized by an absorption band in ethanol solution centered at about $517 \mathrm{~nm}$. When a solution of DPPH is mixed with that of a substance that can donate a hydrogen atom, then this gives rise to the reduced form with the loss of violet color. DPPH radical is representing by $\mathrm{Z}^{*}$ and the donor molecule by $\mathrm{AH}$, the primary reaction is presented in Equation 1 given below:

\section{$\mathbf{Z}^{*}+\mathbf{A H}=\mathbf{Z H}+\mathbf{A} *$}

[1]

Where, $\mathrm{ZH}$ is the reduced form and $\mathrm{A}^{*}$ is free radical produced in this first step. This latter radical will then undergo further reactions which control the overall stoichiometry, that is, the number of molecules of DPPH reduced by one molecule of the reductant. The DPPH molecule $Z^{*}$ is then intended to represent the free radicals formed in the system whose activity is suppressed by the substance AH. ${ }^{[11]}$

Research on medicinal plant is an important fact of biochemical research in India because of several reasons. ${ }^{[12]}$ Inflammation is a disorder involving localized increased in the number of leukocyte and a variety of complex mediator molecules. Prostaglandins are ubiquities substance that indicate and modulate cells and tissue responses involved in inflammation. The research in to plants with alleged folkloric use a pain relievers, anti-inflammatory agents should therefore be viewed as a fruit and logical research strategy in the search for new analgesic and anti-inflammatory drugs. ${ }^{[13]}$ Because synthetic molecule like no steroidal anti-inflammatory drugs (NSAIDSs) and COX-2 inhibitor that increase the incidence of adverse cardiovascular thrombotic effects so in order to overcome, there is need to focus on scientific exploration of herbal drugs. ${ }^{[14]}$ The fruit of Solanum nigrum (Family Solanaceae) has been reported in the ancient Indian herbal medicine with beneficial Inflammation, Tuberculosis, diuretic, antimicrobial, antibacterial etc. ${ }^{[15]}$ The present study is design to investigate the antiinflammatory effect in Solanum nigrum in acute and chronic inflammation.

\section{MATERIAL AND METHOD}

\section{Chemicals}

1, 1- diphenyl-2-picryl-hydrazyl was purchased from Hi Media Laboratories Pvt. Ltd. Butylated hydydroxytoluene and methanol was purchased from Rankem RFCL limited. TRIS [ 2-amino-2 (hydroxyl methyl) propane 1-3 di-ol] buffer (pH7.4) was purchased from Qualigen Fine Chemicals.

\section{Plant material}

The fruits of S. nigrum were purchased from the Khari Bawli Old Delhi and the Herbarium specimen was identified from NBPGR New Delhi.

Preparation of extract
The shade dried powders of fruits extracted in a Soxhlet apparatus with methanol gave $23 \%$ extract.

\section{Preparation of reagents}

The $500 \mu \mathrm{M}$ solution of DPPH was prepared by dissolving $23 \mathrm{mg}$ of DPPH in $100 \mathrm{ml}$ of methanol. TRIS [2-amino-2 (hydroxyl methyl) propane 1-3 di-ol] buffer ( $\mathrm{pH}$ 7.4) was prepared by adding $0.605 \mathrm{~g}$ of TRIS buffer in $30 \mathrm{ml}$ of water and adding $0.33 \mathrm{ml}$ of concentrated hydrochloric acid, diluted to $100 \mathrm{ml}$ with distilled water. The TRIS buffer prevents the sudden $\mathrm{pH}$ change during the preparation of test dilutions.

\section{Preparation of reference standard solution}

Various dilutions of butylated hydroxytoluene were made with concentration of $5,10,15,20,25,30,35,40,45 \& 50 \mu \mathrm{g}$ per 0.5 $\mathrm{ml}$ of methanolic solution of butylated hydroxytoluene.

Preparation of sample solution and dilutions

Prepared the stock solution by dissolving $250 \mathrm{mg}$ methanolic extract of Solanum nigrum fruits and made up the volume to $25 \mathrm{ml}$ with methanol. Prepared the initial dilutions from stock solution using volume $0.25 \mathrm{ml}, 0.5 \mathrm{ml}, 0.75 \mathrm{ml}, 1.0 \mathrm{ml}, 1.25 \mathrm{ml}, 1.50 \mathrm{ml}$, $1.75 \mathrm{ml}, 2.0 \mathrm{ml}, 2.25 \mathrm{ml}$ and $2.5 \mathrm{ml}$ are dilute up to $10 \mathrm{ml}$ with methanol. The final concentrations used for taking the absorbance are $0.25 \mathrm{mg}, 0.50 \mathrm{mg}, 0.75 \mathrm{mg}, 1.00 \mathrm{mg}, 1.25 \mathrm{mg}, 1.5 \mathrm{mg}, 1.75 \mathrm{mg}$, $2.00 \mathrm{mg}, 2.25 \mathrm{mg}$ and $2.5 \mathrm{mg}$ per $\mathrm{ml}$.

Animal

Adult Wister rats of both sexes weighting between 200-250g was used for experiment. They were housed in standard environmental condition like, ambient temperature $\left(25^{\circ} \mathrm{C}\right)$ relative humidity $(55-$ $60 \%$ ) and 12/12h light dark cycle. Animal had free access to standard pellet diet and water ad libitum.

\section{Measurement of in-vitro antioxidant activity ${ }^{[16]}$}

The antioxidant activity of the fruit of $S$. nigrum was determined by using a method based on the reduction of methanolic solution of colored free radical 1, 1 di phenyl-1-2 picryl hydrazyl (DPPH). The radical scavenging activity of tested sample was expressed as an inhibition percentage. Butylated hydroxyl toluene was used as reference standard. In $5 \mathrm{ml}$ volumetric flasks added $1 \mathrm{ml}$ of DPPH solution, $0.5 \mathrm{ml}$ of TRIS buffer and $0.5 \mathrm{ml}$ of final dilutions of different concentrations range prepared from $S$. nigrum stock solution and made up the volume to $5 \mathrm{ml}$ with methanol. Similarly, control dilutions of DPPH were prepared, replacing $0.5 \mathrm{ml}$ of prepared dilutions (the test drug solution) with methanol. The absorbance of all the dilutions was taken after 30 minutes at $\lambda$ max $517 \mathrm{~nm}$ using methanol as blank.

Statistical analysis

The percentage inhibition was calculated using Equation 2: 
Percent inhibition $=\left(\mathbf{A}_{\mathrm{c}}-\mathbf{A}_{\mathbf{S}}\right) \mathbf{X 1 0 0 / A _ { C }}$

Where, $\mathrm{A}_{\mathrm{c}}=$ Absorbance of control;

$\mathrm{A}_{\mathrm{S}}=$ Absorbance of sample

$\mathrm{IC}_{50}$ value (a concentration at $50 \%$ inhibition) was determined from the curve between percentage inhibition and concentration. All determinations were done in triplicate and the $\mathrm{IC}_{50}$ value was calculated by using the equation of line and standard plot.

Anti inflammatory activity by Carrageenan induced rat paw edema method ${ }^{[17]}$

Albino rat of either sex weighing 200-250gm was divided in 4 groups $(\mathrm{N}=6)$. Group-1 received 0.5\% $\mathrm{CMC}$ suspension (control) group 2, 3 and $4^{\text {th }}$ methanolic extracts $(125,250$ and $375 \mathrm{mg} / \mathrm{kg}$ ) of S. nigrum respectively. Group 5 received diclofenac (reference standard $1 \mathrm{mg} / \mathrm{kg}$ ). Animal were treated with drugs by oral route and subsequently $1 \mathrm{~h}$ after treatment $0.1 \mathrm{ml}$ of $1 \%$ suspension of carrageenan in normal saline was injected into the sub planter region of left hind paw to induce edema. The paw volume was measure initially at $0,1,2,3$ and $4^{\text {th }}$ after carrageen injection using digital paw edema meter (520-R, IITC, life science-USA). The difference between the initial and subsequent values gave the actual edema volume which was compare with control. The inhibition of the inflammation was calculated using the formula as given in Equation 3:

$\%$ inhibition $=100\left(1-V_{t} / V_{c}\right)$

[3]

Where, $\mathrm{V}_{\mathrm{c}}=$ edema volume in control;

$\mathrm{V}_{\mathrm{t}}=$ edema volume in the group treated with test extracts.

\section{RESULT \& DISCUSSION}

Polyphenolic compounds like flavonoids and phenolic acids, commonly found in plants, have been reported to have multiple biological effects, including antioxidant activity. The present study demonstrates the $S$. nigrum has moderate free radical scavenging action. Antioxidant property of S. nigrum can be attributed to the presence of flavonoids and polyphenols and which in turn may be responsible for its anti-stress effect.

The methanolic extract of S. nigrum tested for in vitro using DPPH showed moderate free radical scavenging activity, as evidenced by low $\mathrm{IC}_{50}$ values with respect to standard BHT. Figure 1 and Figure 2 shows the free radical scavenging trend of standard BHT and methanolic extract of S. nigrum. was found to be 326.481 .

The absorbance of sample (methanolic extract of S. nigrum and standard butylated hydroxytoluene) were taken in triplicate. With the increase of concentration of test drug, the decrease of absorbance value and the calculated percentage inhibition has been shown with the help of Table 1 and Table 2 whereas graphical presentations were given in Figure 1 and Figure 2 respectively.
Table1: Absorbance and percentage inhibition of DPPH by methanolic extract of $S$. nigrum

\begin{tabular}{|c|c|c|}
\hline $\begin{array}{c}\text { Concentration } \\
(\mathbf{m g} / \mathbf{m l})\end{array}$ & Absorbance & $\begin{array}{c}\text { Percentage } \\
\text { inhibition }\end{array}$ \\
\hline 125 & 0.931 & 50.34 \\
\hline 375 & 0.890 & 52.53 \\
\hline 500 & 0.743 & 60.37 \\
\hline 625 & 0.627 & 66.56 \\
\hline 750 & 0.505 & 73.06 \\
\hline 875 & 0.367 & 80.42 \\
\hline 1000 & 0.242 & 87.09 \\
\hline 1125 & 0.189 & 89.92 \\
\hline 1250 & 0.181 & 100.00 \\
\hline
\end{tabular}

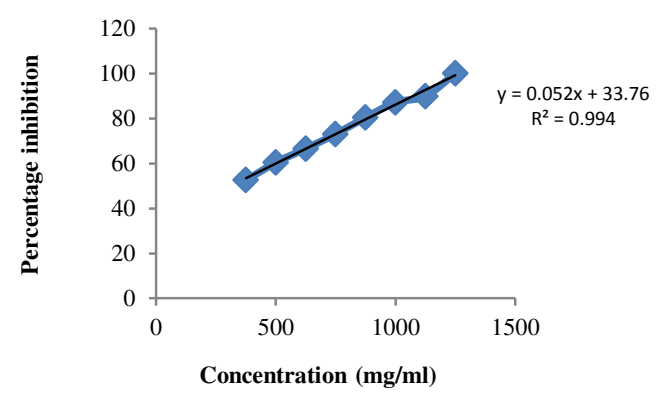

Figure 1: Graphical representation of free radical (DPPH) scavenging activity of $S$. nigrum in-vitro systems.

Table 2: Absorbance and percentage inhibition of DPPH by standard methanolic solution of butylated hydroxytoluene (BHT)

\begin{tabular}{|c|c|c|}
\hline $\begin{array}{c}\text { Concentration } \\
(\boldsymbol{\mu} \mathbf{g} / \mathbf{m l})\end{array}$ & Absorbance & Percentage inhibition \\
\hline $\mathbf{0}$ & 0 & $\mathbf{0}$ \\
\hline 5 & $2.163 \pm 0.01$ & 7.78 \\
\hline 10 & $1.996 \pm 0.04$ & 14.91 \\
\hline 15 & $1.792 \pm 0.06$ & 23.58 \\
\hline 20 & $1.601 \pm 0.02$ & 31.75 \\
\hline 25 & $1.531 \pm 0.09$ & 34.72 \\
\hline 30 & $1.375 \pm 0.00$ & 41.36 \\
\hline 35 & $1.211 \pm 0.01$ & 48.36 \\
\hline 40 & $1.111 \pm 0.00$ & 52.62 \\
\hline 45 & $0.945 \pm 0.01$ & 59.69 \\
\hline 50 & $0.892 \pm 0.01$ & 61.94 \\
\hline
\end{tabular}

The effect of methanolic extract of S. nigrum (125, 250 and 375 $\mathrm{mg} / \mathrm{kg}$ ) in carrageenan induced paw edema in rats was also studied. The methanolic extract of S. nigrum $(375 \mathrm{mg} / \mathrm{kg})$ prevented the formation of edema induced by carrageenan as shown in Table 3 . This showed significant anti-inflammatory activity $(\mathrm{p}<0.05)$. The methanolic extract of $S$. nigrum $(375 \mathrm{mg} / \mathrm{kg})$ reduced the edema induced carrageenan by after $3 \mathrm{hr}$ injection of noxious agent as compared to the control vehicle treated group. Diclofenac group at $10 \mathrm{mg} / \mathrm{kg}$ inhibited the edema volume. In carrageenan induced 
acute inflammation model, the methanolic extract $(375 \mathrm{mg} / \mathrm{kg})$ produced better inhibition of paw edema. Carrageenan an induced edema commonly used as experimental animal model for acute inflammation and is believed to be biphasic. The early phase (1$2 \mathrm{hr}$ ) of the carrageenan model is mainly mediated by histamine, serotonin and increased synthesis of prostaglandins in the damaged tissue surrounding. The late phase is sustained by prostaglandin release and mediated by bradykinins, leucotriens polymorphonuclear cells and prostaglandin produced by tissue macrophages. The significant inhibitory activity shown by methanolic extract of $S$. nigrum fruits $(125,250$ and $375 \mathrm{mg} / \mathrm{kg}$ ) over a period of $4 \mathrm{hr}$ in the carrageenan-induced inflammation was quite similar to that exhibited by the group treated with standard anti-inflammatory drug diclofenac sodium. The highest $31 \%$ inhibition activity was found at a dose of $375 \mathrm{mg} / \mathrm{kg}$ after $4 \mathrm{hr}$ of extract administration as shown in Table 4.

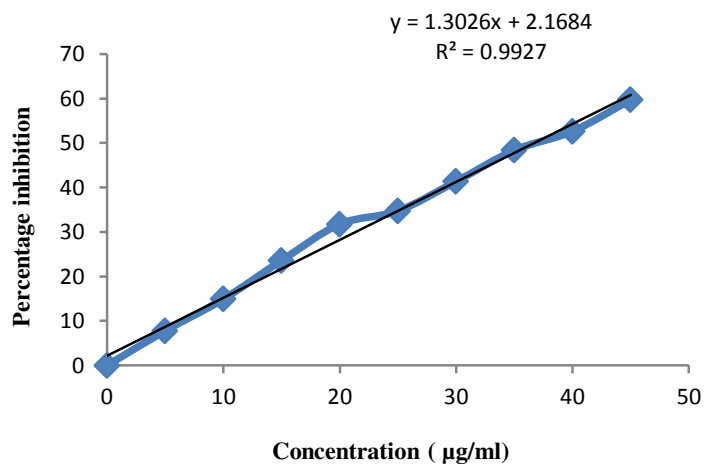

Figure 2: Graphical representation of free radical (DPPH) scavenging activity of standard antioxidant butylated hydroxytoluene (BHT).

Table 3: Effect of methanolic extract of fruits of $S$. nigrum on carrageenan induced paw edema in rats

\begin{tabular}{|c|c|c|c|c|c|c|}
\hline \multirow{2}{*}{$\begin{array}{c}\text { Treatment group } \\
(\mathbf{n = 6})\end{array}$} & Dose(mg/kg) & \multicolumn{5}{|c|}{ Edema diameter (cm) } \\
\cline { 3 - 7 } & & $\mathbf{0 h r}$ & $\mathbf{1 h r}$ & $\mathbf{2 h r}$ & $\mathbf{3 h r}$ & $\mathbf{4 h r}$ \\
\cline { 3 - 7 } & & & & & & \\
\hline Normal saline (Control) & $10 \mathrm{ml} / \mathrm{kg}$ & $0.94 \pm 0.002$ & $0.97 \pm 0.002$ & $0.74 \pm 0.002$ & $1.03 \pm 0.01$ & $1.05 \pm 0.02$ \\
\hline Methanolic extract & 125 & $0.87 \pm 0.025$ & $0.84 \pm 0.008$ & $0.85 \pm 0.007$ & $0.84 \pm 0.01$ & $0.78 \pm 0.03$ \\
\cline { 2 - 7 } & 250 & $0.90 \pm 0.007$ & $0.92 \pm 0.01$ & $0.86 \pm 0.007$ & $0.86 \pm 0.002$ & $0.84 \pm 0.002$ \\
\cline { 2 - 7 } & 375 & $0.81 \pm 0.008$ & $0.80 \pm 0.002$ & $0.79 \pm 0.006$ & $0.77 \pm 0.02$ & $0.75 \pm 0.002$ \\
\hline Diclofenac (Standard) & 10 & $0.90 \pm 0.002$ & $0.91 \pm 0.002$ & $0.89 \pm 0.002$ & $0.88 \pm 0.04$ & $0.83 \pm 0.002$ \\
\hline
\end{tabular}

Table 4: Percentage inhibition of paw edema by methanolic extract of fruits of $S$. nigrum

\begin{tabular}{|c|c|c|c|c|}
\hline \multirow{2}{*}{$\begin{array}{c}\text { Treatment group } \\
(\mathbf{n = 6})\end{array}$} & \multicolumn{4}{|l|}{ Percentage inhibition(\%) at various time interval } \\
\cline { 2 - 5 } & $\mathbf{1 h r}$ & $\mathbf{2 h r}$ & $\mathbf{3 h r}$ & $\mathbf{4 h r}$ \\
\hline $\begin{array}{c}\text { Methanolic extract } \\
125 \mathrm{mg} / \mathrm{kg}\end{array}$ & 11.40 & 12.37 & 18.00 & 28.00 \\
\hline $\begin{array}{c}\text { Methanolic extract } \\
250 \mathrm{mg} / \mathrm{kg}\end{array}$ & 3.15 & 9.34 & 16.00 & 23.00 \\
\hline $\begin{array}{c}\text { Methanolic extract } \\
375 \mathrm{mg} / \mathrm{kg}\end{array}$ & 15.52 & 16.55 & 25.00 & 31.00 \\
\hline
\end{tabular}

\section{CONCLUSION}

The result obtained from experiment is concluded that the methanolic extract of $S$. nigrum $(375 \mathrm{mg} / \mathrm{kg})$ having good inflammatory activity and it dose dependent activity. The methanolic extract of solanum nigrum fruit showed significant antioxidant activity in vitro by using DPPH solution

AKNOWLEDGEMENT

IJPER, 2019, Volume 1, Issue 1, 1-5 
Authors are highly thankful to the Principal, Department of Pharmacy, Ram-Eesh Institute of Vocational and Technical Education, Greater Noida, Uttar Pradesh, India for providing necessary infrastructure for undertaking the project.

\section{REFERNCES}

1. Srikumar S, Athem M, Sukumar M, Ravi TK. HPTLC method for standardization of Curculigo orchioides rhizomes and its marketed formulation using Gallic acid as standard. Indian Journal of Pharmaceutical Sciences. 2005; 67(6): 721-724.

2. Dorman HJD, Dean SG. Antimicrobial agents from plants antibacterial activity of plant volatile oils. Journal of Applied Microbiology. 2000; 88(2): 308316.

3. Kaushik R, Jain J, Mazumdar A, Singh L. Studying the pharmacological basis of an antiepileptic Ayurvedic formulation-Sarasvata Churna. International Journal of Green Pharmacy. 2017; 11(2):62-68.

4. Su YZ. Recent natural product based drug development: A pharmaceutical industry perspective. Journal of natural products. 1998; 61(8): 1053-1071.

5. Purohit SS, Mathur SK. Drugs in biotechnology fundamental and application. Maximillan publication, India.1999; 576.

6. Ayurvedic pharmacopoeia ( 1996), Ministry of Health and family welfare, Govt. of India, New Delhi 1(1);43

7. Ministry of Ayush, Government of India, The Ayurvedic Pharmacopoeia of India, Part-1, vol. IX, New Delhi: Pharmacopoeia Commission for Indian Medicine \& Homoeopathy, 2016.

8. Kirtikar KR, Basu BD, Indian Medicinal Plants, Vol. III. Dehradun: Bishen Singh Mahendra Pal Singh, 2003, 1752-1754.

9. Patt DE and Hudson BJF. Natural antioxidant not exploited commercially in food antioxidants, London: Elsevier Applied Science, 1990; 171-191.

10. Dekkers JC, Doornen LJP, Han CG. The role of antioxidant vitamins and enzymes in the prevention of

\section{CONFLICT OF INTEREST}

Authors do not have any conflict of interests.

exercise-induced muscle damage. Sports Medicine. 1996; 21(3): 213-238.

11. Kaczmarski M, Wojiciciki J, Samochowiee L, Dutkiewicz T, Sych Z. The influence of exogenous antioxidants and physical exercise on some parameters associated with production and removal of free radicals. Pharmazie. 1999; 54(4): 303-306.

12. Molyneux $P$. The use of stable free radical diphenylpicrylhydrazyl (DPPH) for estimating antioxidant activity. Songklanakarin Journal of Science and Technology. 2004; 6(2): 211-219.

13. Chopra RN, Chopra IC, Nanda, Kapoor LD. Indigenous Drug of India. Calcutta: UN Dhar and Sons Pvt, 1958; 524.

14. Gupta M, Mazumder UK, Gomathi P, Thamilselvan V. Anti-inflammatory evaluation of leaves of Plumeria acuminate. BMC Complementary and alternative medicine. 2006; 6(36):1472-6882.

15. Chaudhary MA, Abdellatif KRA, Don Y, Das D, Suresh MR, Knaus EE. Synthesis of celecoxib analogue possessing a N-difluromethyl-1, 2- Dihydropyrid-2-one S-lipoxygenase pharmacophore: biological evaluation as dual inhibitors of cycloxygenase. Journal of Medicinal Chemistry. 2009; 52(6); 1525-1529.

16. Gupta D, John PP, Kumar P, Jain J. Evaluation of antioxidant activity of unripe Aegle marmelos Corr. fruits. Journal of Applied Pharmaceutical Sciences and Research. 2018; 1(1):4-7.

17. Damor B, Gaur K, Dashora A, Parra SA. Evaluation of analgesic and anti-Inflammatory activity of methanolic extract of Guazuma Ulmifolia. Journal of Applied Pharmaceutical Sciences and Research. 2018; 1(4): 2329.

IJPER, 2019, Volume 1, Issue 1, 1-5 